\title{
Professionalism, Competency and Financial Reporting Quality: A Perception of Director of Finance in a Changing Public Sector Reporting Standard (Kualiti Profesionalisme, Kecekapan dan Pelaporan Kewangan: Persepsi Pengarah Kewangan dalam Pelaporan Sektor Awam yang Berubah Piawai)
}

\author{
Maruf Mustapha \\ (Department of Local Government And Development Studies, Ahmadu Bello University) \\ $\mathrm{Ku}$ Nor Izah Ku Ismail, \\ Halima Nasibah Ahmad \\ (Tunku Peteri Intan Safinaz School of Accountancy, Universiti Utara Malysia)
}

\begin{abstract}
The Financial Reporting Quality (FRQ) refers to better information dissemination across different users. It remains a prevalent factor for organizations' performance and survival. The public sector in many countries, have witnessed considerable changes in the past decades. The prominent one being the International Public Sector Accounting Standards (IPSAS) for the public sector entities. Drawing on contingency and institutional theories, this study examine the perception of directors of finance regarding the effects of professionalism on the relationship between staff competency and FRQ under a new accounting standard. Using survey research approach and self-administered questionnaire, data were gathered from 118 directors of finance representing local governments of four States in the north-west geographical zone of Nigeria. The Partial Least Squares Structural Equation Modeling (PLS-SEM) revealed a significant positive relation between staff competence and FRQ. Conversely, no significant effect was found in the interaction of professionalism on the model. The study implication was discussed in the context of Nigeria.
\end{abstract}

Keywords: Financial reporting quality: competence: professionalism: theory

ABSTRAK

Kualiti pelaporan kewangan (KPK) merujuk kepada penyebaran maklumat yang lebih baik merentasi pengguna yang berbeza. Oleh itu, KPK menjadi faktor yang penting untuk prestasi dan kelangsungan kewujudan sesebuah organisasi. Sektor awam di kebanyakan negara telah menyaksikan perubahan ketara dalam beberapa dekad yang lalu. Antara yang penting adalah Piawaian Perakaunan Sektor Awam Antarabangsa (IPSAS) untuk entiti-entiti sektor awam. Berdasarkan kepada teori kontinjensi dan teori institusional, kajian ini menguji kesan profesionalisme ke atas hubungan antara kecekapan staf dan KPK di bawah piawaian perakaunan baru. Dengan menggunakan pendekatan penyelidikan tinjauan dan soal selidik, data telah dikumpulkan daripada 118 pengarah kewangan di kerajaan-kerajaan tempatan dari empat buah negeri yang terletak di zon geopolitik utara-barat Nigeria. Keputusan daripada analisis yang menggunakan "Partial Least Squares Structural Equation Modelling" (PLS-SEM) menunjukkan hubungan positif yang signifikan antara kecekapan staf dan KPK. Sebaliknya, tiada kesan yang signifikan ditemui dalam interaksi profesionalisme terhadap model kajian. Implikasi kajian dibincangkan dalam konteks Nigeria.

Kata kunci: Pelaporan kewangan: kualiti: kecekapan; profesionalisme; teori

\section{INTRODUCTION}

Financial Reporting Quality (FRQ) has been described as a pervasive phenomenon and is costly to organizations (Gjorgieva-Trajkovska, Koleva \& Nikoloski 2017). Studies have shown that deficiencies in the quality of financial statement may not only cause substantial loss to an organization annually, but may have negative and adverse effects on it going concern and growth (Jara, Ebrero, \& Zapata 2011; Tarus, Muturi \& Kwasira 2015). Instances of collapse of big private organizations abound (e.g. Enron in 2001, WorldCom in 2002, Saytan in 2009), while financial mismanagement and fraud that pervade the public sector have been directly linked to compromise in the quality of financial reports disclosed by managers ( Nyor 2013; Tasios \& Bekiaris 2012). Thus, it is doubtful whether the quality of financial reports emanating from corporate organizations can satisfy the information needs of diverse user groups in terms of its reliability and relevance.

However, general inference from accounting theories has shown that, the value of accounting report lies in the ability of the financial statement to provide accurate and fair information about the underlying financial 
position and economic performance of an entity (Herath \& Albarqi 2017). The central importance of quality in accounting reporting refers to better information dissemination across different users, in which financial reports reveal what they purport to communicate to users of the information (Hope 2003; Pounder 2013).

As a consequence, public sector organizations in many countries have adopted several reforms and made considerable changes to their operations over the last three decades or so (Laswad \& Redmayne 2015). Prominent among these changes lies in the entrenchment of the New Public Management (NPM) philosophy to strengthen the operation of public organizations (Hood 1995; Pina \& Torres 2003). The NPM reforms involve the achievement of new management practices through privatization, commercialization, decentralization, and output orientation, amongst other things (Hyndman \& Connolly 2011). Within the NPM initiatives, the public sector organizations witnessed significant transformation in the area of financial reporting to incorporate accrual accounting principles (Guthrie, Olson \& Humphrey 1999). According to Broadbent and Guthrie (2008), the NPM reforms include attempts to institutionalize accrual accounting for budgetary and external financial reporting purposes in order to provide useful information about liabilities, debts, usage of assets and the cost of public services.

To achieve the NPM framework, the International Federation of Accountants (IFAC) together with the International Accounting Standards (IAS) submitted the "Guidelines for Governmental Financial Reporting" to assist governments at all levels in the preparation of their financial reports based on accrual accounting basis (Pina, Torres \& Yetano 2009). This consequently provided the basis for the introduction of International Public Sector Accounting Standards (IPSAS) in the recent time. Though, the scope and format of adoption of IPSAS among constituencies differ significantly (Brusca \& Martınez 2015).

Nonetheless, the underlying principle of IPSAS fundamentally demonstrates a shift from the traditional cash basis to accrual accounting system which is aligned with the practice in private sector (IFRS) (Brusca \& Martınez 2015). Although, the alignment of IPSAS with the IFRS has been largely criticized on grounds of fundamental differences between the public and private sector (Anessi-Pessina, Nasi \& Steccolini 2008; Balios, Poutos \& Toudas 2013). Meanwhile, in 2002, IFAC introduced standards that have specific significance to the public sector (IASB 2010; IPSASB 2010), resulting to four public sector specific standards. Namely, IPSAS 21 on impairment of non-cash generating assets; IPSAS 22, general government sector reporting; IPSAS 23 on revenues from nonexchange transactions; and IPSAS 24 on budget information disclosure and one standard based on comprehensive cash basis IPSAS.

From global viewpoint, lessons learnt in the implementation of IPSAS across different countries/nations have made significant contribution to its evolution and development over time (Bisogno, Santis \& Tommasetti 2015; Young \& Mouck 2012). Yet, there is paucity of studies in the context of developing countries that investigated one or more of the public sector specific standards and test the significance of same on quality of financial reporting outcomes. For example, standards based on the cash-basis IPSAS have received less attention, despite its envisaged significance as the de facto standard widely adopted by developing countries (Chan 2008; Pina \& Torres 2003). The cash-basis IPSAS issued in 2003 was envisaged as a means of increasing the performance of accounting with a view to imbibing the internationally agreed minimum benchmarks of best practices in accounting and reporting (Adhikari, Kuruppu \& Matilal 2013).

Generally, the prevalence of the adoption of cash-basis IPSAS in the context of developing countries can be attributed to: (1) as part of requirement specified by international financial institutions (e.g. World Bank, African Development Bank, Asian Development Bank) to access aids, grants, and loans provided to developing nations (Chan 2008; Torres 2004). (2) the standard is being acknowledged by the professional accounting bodies (IFAS, IAS, and IPSASB) to serve as the best government accounting alternatives for developing nations lacking internationally approved regulations and standards (Chan 2008) and (3) serves as initial step for developing countries as a means of elevating their accounting capacity and competence needed for the adoption of accrual accounting in the long run (Adhikari \& Mellemvik 2010). Besides, unlike the accrual basis IPSAS, the structural and technical requirements for implementation of the cash-basis IPSAS is simpler and more attuned to the traditional cash base reporting system previously in use among constituencies in developing countries (Mustapha, Ku Ismail \& Ahmad 2017; Patel \& Prasad 2013).

Therefore, the result of the observed gap if not bridged may limit generalization on the progress achieved so far regarding adoption of accounting standard (IPSAS) as a whole. In addition, existing and potential adopters of the standard may loss vital information and guide regarding how to improve on the existing operations prior to adoption of the full accrual IPSAS in the future.

Contextually, Nigeria adopted the cash-basis IPSAS in 2014 across it three tiers of government. Due to its standardized framework, the standard has been described as a higher quality accounting standards which surpassed the traditional cash basis previously in use (Ayobami 2014; Nongo 2014). Despite this, no known study in respect of Nigeria has tested the efficacy of the standard and benefits on FRQ within a given organization contingency. The few available studies only focused on cost and benefit of the accounting reform without empirically assessing its effect on FRQ. (e.g. Akhidime \& Ekiomado 2014, 2011; Herbert, Ene \& Tsegba 2014). 
Furthermore, following the adoption of the cash-basis IPSAS in Nigeria, extant studies have identified some potential challenges the public sector entities may encounter in the cause of implementation. These include: lack of developed legal and regulatory framework (Maigoshi 2014), low level of awareness among participants (e.g. preparers, users, investors etc.) (Madawaki 2014), shortage of skilled and competent accounting staff (Garuba \& Donwa 2011; Musa 2015), absence of institutions for education and professional capacity building for practitioners and managers (Herbert et al. 2014), to mention a few. Despite these noteworthy studies, less attention is paid to assessing the effect of competency of accounting staff on the elaboration of quality financial reporting in the context of Nigerian public sector.

Moreover, comprehensive literature review that examined the effect of one or more of the above factors on FRQ previously, revealed confounding results, including the relationship between staff competence and FRQ (Abbott et al. 2016; Herbert et al. 2014; Herath \& Albarqi 2017). This suggests that more studies are needed to enhance precision in results. Therefore, to add to existing literature on the subject, the present paper introduced a moderating variable in terms of professionalism to ameliorate this observed gap.

The concept of professionalism was incorporated as a moderator in the study's model because: first, findings from prior studies revealed that, professionalism associate positively with adoption of accounting standards and FRQ (e.g. Christiaens 1999; Darwanis, Saputra \& Kartini 2016). Thus, professionalism has a strong positive connotation (Svensson 2006) which can strengthen the confounding interaction between staff competence and FRQ. This is consistent with Baron and Kenny's (1986) argument that a moderator is introduced in a model when the link between dependent and independent variables are confounding or weak. Second, given that the diffusion of professionalism in the work place may enhance existing competence capacity of staff through development and support for professional proficiency in skills, ethics and engagement in norms of best practice of professional institutions, make the concept germane to be applied as a potential moderator to the study (Khumawala, Marlowe \& Neely 2014).

Against this backdrop, we theorized to understand whether professionalism matters in strengthening the relationship between competency and FRQ during the international accounting reform. The investigation of professionalism as a possible moderator in the analysis of competency/FRQ relations is yet to be studied. Therefore, considering this in the present paper may add to our theoretical insight and provide empirical evidence on how professionalism could influence the relationship between competency and financial reporting quality. Although, the two terms (competence and professionalism) may be viewed as synonymous, but reference to extant literature indicated a divide between the concepts (Khumawala et al. 2014; Svensson 2006). For instance, Khumawala et al. (2014) argued that, while professionalism involve a specialized technical capabilities and training by designated institution, competence involve the acquisition of basic capabilities to perform a job. This suggest that professionalism has an edge over competency requirement to perform a specific task.

Contextually, application of the two concepts (professionalism and competence) can be distinguished in the way recruitement of staff are done in the Nigerian public service. For instance, local government employees are sometimes recruited not necessarily based on their professional/specialized qualification, rather, based on the fufilment of minimum required qualifications, among other things (e.g. Diploma, Higher Diploma, First Degree etc.). Accordingly, in the context of this paper, the demographic profile of respondents indicates that, employees with basic/minimum educational qualification constitute most of the employees of the finance department out of which few of them are professionals in related accounting field (see Table 2). Thus, defferentiating those with basic qualification (competence) from those with specialized capabilities (professionals).

Therefore, the objective of this study is to report the findings of a survey based on the perceptions of director of finance (preparers) of local governments about a variety of issues regarding professionalism, staff competency and attributes of financial reporting quality after adoption of the cash-basis IPSAS in Nigeria. The choice of director of finance as respondents for this study is based on the understanding that, they are competent stakeholders with the required knowledge and experience on local government accounting system and operations. Again, large area of prior studies have focused largely on the users' perspective (Jonas \& Blanchet 2000; Nyor 2013), while studies on the preparers' perspective are still very scanty. Thus, this study contributes to the study on preparers' perception on quality of accounting reporting which will add to our understanding regarding the efficacy of international accounting standards.

Therefore, the remaining parts of the paper proceed as follows. Section 2 provides the study's literature review. Section 3 describes the methodology. Section 4 contains the measurement for the study. Section 5 provides the study's results. Section 6 involves the study's implication. Finally, section 7 concludes the study. 


\section{Jurnal Pengurusan 57(2019), Galley Proof \\ ISSN 0127-2713 Scopus, Cabell, ASEAN Citation Index (ACI) and MyCite Indexes}

\section{LITERATURE REVIEW}

\section{FINANCIAL REPORTING QUALITY (FRQ)}

FRQ is a concept derived from financial reporting system of economic entities. It is a term widely used in financial accounting research (Bageva 2010). Jonas and Blanchet (2000), state that "quality financial reporting is full and transparent financial information that is not designed to obfuscate or mislead users. In terms of its measurements, methods such as, accrual accounting model (Healy \& Wahlen 1999), value relevance models (Barth et al. 2001, 2008; Maines \& Wahlen 2006), method focusing on specific elements of the annual report (Hirst, Hopkins \& Wahlen 2004) have often been used to measure FRQ in the private sector. While in public sector, FRQ is measured largely through the operationalization of the qualitative characteristics of the financial statement (Braam \& Beest 2013; McDaniel, Martin \& Maines 2002).

Conceptual measurement of the qualitative characteristics of financial reports have been developed by international accounting bodies such as the International Accounting Standard Board (IASB), International Federation of Accountants (IFAC) and the Financial Accounting Standard Board (FASB). This measurement primarily offers a comprehensive perspective for assessing the entire range of qualitative characteristics of the financial report (IASB 2010). Accordingly, qualitative attributes/characteristics such as concept of relevance, faithful representation, understandability, comparability and timeliness are considered as potential qualitative factors that describe FRQ (Cohen 2003; IFAC 2015).

Exposure Draft (ED) by the International Federation of Accountant (IFAC 2009, 2015) indicates that information would be relevant when it makes a difference in the user's decisions making concerning an economic phenomenon. For an accounting information to be faithfully represented, financial report must have reflective feature of the annual report which is complete, neutral and free from material error. Thus, understandability is achieved by the presentation of information in such a way that allows users comprehend the meanings of the items contained in a report. Comparability enables users of accounting information to identify similarities in and differences between two sets of economic phenomena (IASB 2009: 39). Timeliness refers to the amount of time an economic entity takes to make information known to other users (IASB 2010).

The qualitative characteristics of financial reporting model have been adopted at varying combination by different authors (e.g. Braam \& Beest 2013; Cohen 2003; Jonas \& Blanchet 2000; Mbobo \& Ekpo 2016; McDaniel Martin, \& Maines, 2002). The underlying benefit of the model is that, it provides a direct measure of financial reporting quality and covers all aspects of financial reports, including both financial and non-financial information. However this paper focus on two sets of qualitative characteristics, namely, relevance and faithful representation. This is with a view to achieve parsimony in concept development and measurement (Arthur 2011; Berry, Ones \& Sackett 2007). Notwithstanding the trade-off in this approach, we opted for simplicity rather than generalizability as may be inferred by the multidimensional consideration. In the view of Blalock (1979), generalization and simplicity cannot be achieved simultaneously. Moreover, the framework of IASB (2010), IFAC (2009b), referred to the qualitative attributes of relevance and faithful representation as the fundamental qualitative characteristics underlying usefulness of information for users' decision making.

Furthermore, Jonas and Blanchet (2000) are of the view that, the overall objective of financial reporting is to provide users with useful information to make economic decision, and according to the conceptual frame of professional accounting boards (e.g. FASB, IASBs, IFAC), useful financial information must be relevant and be faithfully represented. Nonetheless, Jonas and Blanchet (2000) indicate that, some more specific qualitative attributes related to the two characteristics help determine relevance and faithful representation. For instance, according to Financial Accounting Standards Board (FASB 1980), timeliness is an ancillary aspect of relevance.

\section{ACCOUNTING STAFF COMPETENCY}

The term competence is usually utilized in the realm of human resource management and its exact conceptualization has been widely debated in the literature. Saputra and Hutahaean (2016) indicate that, competence is what people need to know and be able to do to perform their job effectively. According to Dingle (1995), competence is a combination of knowledge, skill and awareness. To avoid ambiguity, Dingle (1995) clarifies this when he states that knowledge refers to the understanding of fundamental principles required to accomplish the task at hand; skill involves the application of this understanding; and awareness (attitudes) refers to the proper application of skill.

The concept has been used in the field of accounting and finance, especially following the global accounting reforms which requires accounting practitioners (manager/preparers) to discharge their duties with utmost competence (Bots, Groenland \& Swagerman 2009; Yaşar, Ünal, \& Zaim 2013).

Theoretically, the significant exigencies of Contingency theory implicitly reveals competency as an endogenous organizational factor that influences organizational performance outcome. Lüder (1992), explored the application of Contingency theory to explain the underlying organizational contingencies and their effects on 
organization's performance. The imperative of the theory examined the diffusion of more innovation in the information system of public sector accounting and the resultant effect on reporting outcome (Chan, Jones \& Lüder 1996). The contextual frame of Luder's Contingency model, adopts four variables including implementation barriers which significantly affects organizational performance. Within the framework, implementation barrier involves the militating organizational factors which if not ameliorated may impede effective organizational performance (Chan et al. 1996). Based on this theoretical stand, poor competence of accounting staff is described as an 'implementation barrier' that may impede the achievement of implementation of accounting standards and subsequently, quality of accounting reporting (Ball, Robin \& Wu 2003).

Scores of research on accounting have adopted the concept of competency as a factor to test accounting reporting outcomes. Result from these studies are inconclusive as they revealed mixed findings. For instance, Dwyer and Wilson (1989) examines managers competency and financial reporting quality in terms of timely accounting reporting. The finding revealed that, mangers with the required educational qualification produces timely financial report in terms of reduced time lag between fiscal year end and the auditor's report date. Next, Nur Afiah and Rahmatika (2014) investigate the influence of competence and internal control on the quality of financial reporting and its implications on good governance. The study revealed among other things that, staff competency has significant effect on the quality of financial reporting. Similarly, Setiyawati (2013) shows that internal accountants' competence have significant effect on quality of financial reporting. This result was reinforced by Saputra and Hutahaean (2016), through regression analysis that, competence of the accountants had positive influence on the quality of evaluation report.

Consistent with the above, Abbott et al. (2016) test the quality of internal audit function (IAF) on financial reporting quality. The study finds competence to be a necessary antecedent of effective IAF and FRQ. In a recent study, Puncreobutr, Chumark and Tipajatuporn (2017) show that accountants' competence of SMEs has significant positive association with quality of financial reports of SMEs in the province of Nayok, in Indonesia.

Conversely, negative findings in regards to the competence/FRQ relation was also documented. For example, Kasim (2015) analyze the effect of the competency of government accountants and implementation of internal control over financial reporting quality. The survey focused on local government work unit as unit of analysis. The result of the analysis indicate that, characteristics of the staff competency has no significant effect on financial reporting quality. The insignificant effect of the relationship was blamed on lack of sound accounting knowledge by the staff handling the preparation of the financial reports. Similarly, Darwanis et al. (2016) examined competency as one variable that influence quality of financial statements in the Regions of Indonesia. The multiple regression estimate revealed among other variables that, the staff's competency contribute insignificantly to the model.

Overall, the review of literature above indicate that, results from past studies on the competence/FRQ are inconsistent. Meanwhile, consequential expectation is that, higher staff competency should lead to increased quality of financial reporting (i.e. significant positive relationship). But inference from the literature review above suggests other plausible alternative explanations for the confounding results which requires additional study. In view of this argument, the following hypothesis was advanced:

\section{$\mathrm{H}_{1} \quad$ Accounting staff competence is positively associated with perceived FRQ}

\section{PROFESSIONALISM}

Professionalism is a multidimensional concept. It means different things in different situations and to different people (Evetts 2013). Professionalism involves specialized technical skills and good judgment expected from a person who is trained to do a job (Evetts 2013). According to Association of Professional Enginneers, Geologists and Geophysicists (2004), a professional is a calling, requiring specialized knowledge, skills and methods underlie by scientific and scholarly principles.

In the realm of accounting, professionalism is the role of accounting that demonstrates responsibility for the performance of the business professionally (Staubus 2004). In other words, accounting professionalism is the performance of accounting with knowledge, understanding, virtue and ethic, and follows the rule and regulations. Based on its nature, the concept of professionalism is referred to as involving accountability, transparency, ethical practice, communication, or specialized skills (Carnegie \& Napier 2010).

The essence of professionalism in the application of accounting principles and practices has a direct relationship with the quality of financial reporting in terms of reliability (Mataira \& Van Peursem 2010), business reputation (Salakji \& Phapruke 2011) and support future data accuracy leading to information useful for decisionmaking (Moehrle et al. 2009). Research has established that professionalism is positively related to FRQ. For example, professionalism has been linked with disclosure quality in governmental financial report. Robbins and Austin (1986), found professionalism to be significantly associated with disclosure quality. Christiaens (1999), examined the cross-sectional difference in compliance rate and level of accounting adoption among Flemish 
Municipalities. The result of compliance index and regression analysis revealed that professionalism significantly influence compliance with accounting standards.

In addition, Salakjit and Phapruke (2011) investigated the effects of accounting professionalism on information usefulness through mediating influences of financial reporting quality. The regression result shows that accounting professionalism has a significant positive effect on accounting quality and information usefulness. Similarly, the content analysis by Bakhtiar and Azimifar (2013) regarding the impact of professional ethics on FRQ. The paper established that professional ethics in accounting profession lead to promotion of quality of financial reporting.

On the contrary, an inverse relationship was hypothesized between indicators of professionalism and timely financial reporting by Dwyer and Wilson (1989). Using a documentary data source regarding 142 cities, the regression analysis revealed a partial relationship (less support) between the two measures used to capture professionalism. This is consistent with the findings of Darwanis et al (2016), who reported partial effect of professionalism in the analysis of professionalism, competence, knowledge of financial management and intensity guidance apparatus on FRQ.

Given the conceptualization nature regarding the professionalism phenomena, the results of the review above reveal that professionalism significantly relates to financial reporting outcomes. Based on this, the following hypothesis is advanced:

\section{$\mathrm{H}_{2}$ Professionalism is positively associated with perceived FRQ}

Furthermore, given the inconsistent findings in the literature regarding the staff competency/FRQ relations, the present paper incorporates factor of professionalism as moderating variable to strengthen the relationship between accounting staff competence and FRQ. Thus, this paper argued that, institution of professionalism could increase the competence of accounting staff towards improved accounting practices especially the elaboration of quality financial reports. We draw this argument from both empirical and theoretical evidences.

First, Khumawala et al. (2014) finds that the level of professional technical attainment has a predictive influence on improved support to enhance the competence of accounting staff. This suggests a significant positive relationship between the complementary role of professional support in the work place and improved staff competence. This is demonstrated through development and support for professional proficiency in skills and ethics, including engagement in norms of best practices of professional institutions.

Secondly, theoretical lessons drawn from Institutional Normative Isomorphic theory (DiMaggio \& Powell 1991), is relevant to the current global accounting reform towards the standardization of accounting reporting and practices. This suggest that, professionalism has a predictive influence and stimulation for adoption of international accounting standards and consequent improvement in FRQ. Based on this, theorists have argued that, educational attainment which is fundamental to development of competence (Espositi, Francesca \& Bosco 2015; Kasim 2015) positively relates to professionalism as a fundamental requirement leading to specialized capabilities (Judge, Li \& Pinsker 2010). This professional capability is induced by the requirement and motivations of the fundamentals of normative institutional pressure which is instilled in organizations. That is, due to internationalization and standardization of accounting practice, normative institutional pressure on organizations allows for the institution of professional competencies to accentuate better application of the reform.

Consequently, based on the review of extant literature and theoretical justifications, professionalism being an explanatory and equally antecedent variable to both factors of organizational contingency (accountant competency) and FRQ, could serve as a viable institutional factor to strengthen the confounding relationship between accounting staff competency and FRQ. Therefore, from the preceding discussion, the following hypothesis is stated.

H3 Professionalism moderate positively the relationship between accounting staff competency and perceived FRQ.

However, based on the theoretical and empirical evidence enumerated above, the conceptual model for the present study is shown in Figure 1. 


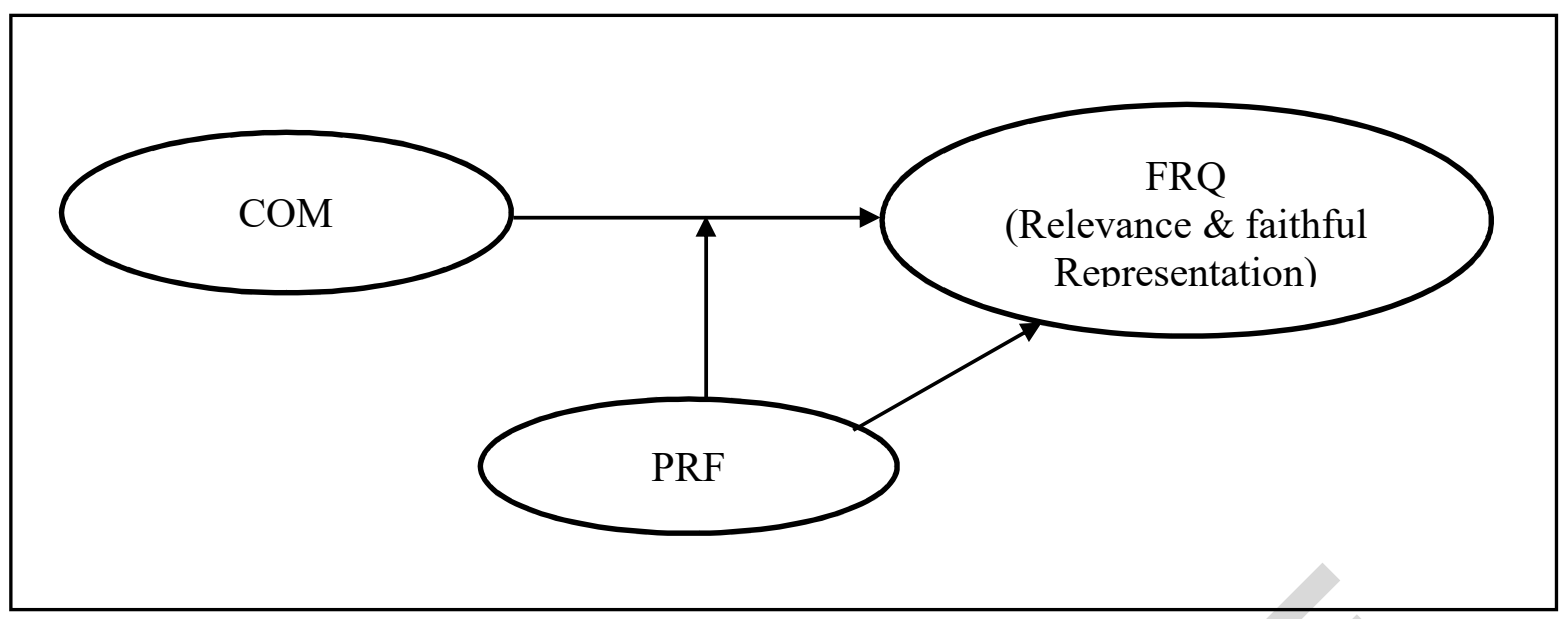

FIGURE 1. Conceptual Model

$F R Q=$ Financial Reporting Quality COM= Staff Competence, $P R F=$ Professionalism

As shown in Figure 1, FRQ is the criterion variable measured by relevance and faithful representation as formative indicators, and the perceived accounting staff competency as the predictor variable. In addition, the framework, shows that professionalism moderates the relationship between accounting staff competence and FRQ.

\section{INTERNATIONAL PUBLIC SECTOR ACCOUNTING STANDARDS}

Public management has witnessed in the recent time reforms towards new management culture with greater emphasis on citizen satisfaction, quality information, transparency and accountability (Jones \& Caruana 2014). The reform culture has been termed New Public Management (NPM). Hood (1995) described it as a new development to reform the public sector and change its operation to a more effective 'market-oriented' management that leads to more cost efficiency for governments (Ashburner, Ferlie \& FitzGeralds 1996).

One intent of NPM reform in the public sector is the standardization of accounting practice among countries of the world. Thus, countries are required to adopt international accounting standards for reporting their economic and financial transactions. But prior to this reform, accounting practice in the public sector has been characterized by using cash-basis accounting system which lacks standardized reporting system. This consequently results to lack of uniform accepted rules, definition, guidelines and comparison among organizations (Chan 2008).

The International Public Sector Accounting Standard Board (IPSASB) of the International Federation of Accountant (IFAC) has issued for adoption set of International Public-Sector Accounting Standards (IPSAS) by governments around the world. This development however, is a shift from the traditional cash-basis to accrualbasis accounting system. Development of IPSAS took its root from the private sector framework. This dates back to the period when the IFAC chose the business accounting model as a reference point that public economic transactions can be prepared with the same criteria as those of business entities (Brusca \& Martınez 2015). Subsequently, the IFAC in 2002 initiated four public sector specific standards including standard based on comprehensive cash basis (IPSASB 2010). The cash basis IPSAS according to Chan (2008) is presumably meant for developing countries that may not be ready to adopt the accrual basis IPSAS at the initial stage.

Due to its standardized framework, the cash-basis IPSAS surpassed the traditional cash basis and the modified-cash basis accounting system, which lacks standardized defined mode as a general accepted accounting system. The cash-basis IPSAS recommends the way in which the General Purpose Financial Statements (GPFS) are to be presented (IFAC 2009a). Furthermore, the cash-basis IPSAS sets out two parts requirements concerning mandatory and optional financial reporting procedures, by which entities designated as complying with cash-basis IPSAS are to adopt as guide for their reporting practices. The first part represents the mandatory requirements which must be complied with. The second part refers to the optional/non-mandatory provisions that stipulates additional accounting policies and disclosure, which an entity is encouraged to adopt in order to enhance its financial accountability and transparency (Adhikari \& Mellemvik 2010). 


\section{METHODOLOGY}

\section{SAMPLE AND DATA COLLECTION}

The study's unit of analysis includes the 124 local government councils that formed the four States drawn from the Northwest geographical zone of Nigeria (Kaduna, Kano, Katsina and Sokoto). Data were collected from a total of 118 directors of finance representing the sample local governments. Data collected relates to information representing their perception regarding their respective local governments. Directors of finance were selected as subjects for the research based on the understanding that they possessed the required knowledge and experience about local government accounting and operations. This understanding is consistent with the views of Larcker and Lessig (1980) that argue that managers (preparers) possess sufficient insight based on their decision process to specify financial information they consider useful.

Further, self-reported questionnaires were personally administered to the sample local government councils. To reduce the effects of Common Method Variance (CMV) and to ascertain the goodness of the questionnaire instrument, several procedural remedies and reliability test were adopted. The effect of CMV was reduced through elimination of ambiguous items from the questionnaire, allowing for respondents' anonymity and avoiding respondents' evaluation apprehension.

With regards reliability test, a pilot test survey was initially carried out according to the guideline by Diamantopoulos and Siguaw's (2006), Cooper and Schindler (2006). Accordingly, 45 questionnaires were distributed to sampled accounting students pursuing Master's and Doctoral degrees in Ahmadu Bello University Zaria, Nigeria, including some local government staff in Sabon Gari and Zaria local government councils, Kaduna State Nigeria. Only 33 questionnaires were completed and returned, forming about $73 \%$ response rate. Subsequently, SPSS 21.0 software was used to calculate the Cronbach's alpha coefficient (Sekaran \& Bougie, 2010) to obtain the internal reliability coefficients of the instrument. Meanwhile, Bagozzi and Yi (1988) as well as Hair et al. (2011) suggested that the internal reliability coefficient should be at least .70 or more for the items to be used. Table 1 presents the reliability coefficients of the respectives construct as shown by their Cronbach's alpha.

TABLE 1. Internal reliability test of constructs

\begin{tabular}{llcc}
\hline Construct & Code & No. of Item & Cronbach's Alpha \\
\hline Financial Reporting Quality & FRQ & 4 & 0.876 \\
Accounting Staff Competence & COM & 4 & 0.945 \\
Professionalism & PRF & 5 & 0.845 \\
\hline
\end{tabular}

As shown in Table 1, based on the threshold of 0.70 , the result generated for this study shows that all measures attained high reliability coefficient, ranging from 0.845 to 0.952 , i.e. each exceeding the minimum acceptable level of .70. This suggests that adequate internal consistency reliability of the measures as used in the pilot study was achieved (Bagozzi \& Yi 1988; Hair et al. 2011). Table 2, present the demographic profile of the respondents.

TABLE 2. Profile of respondents

\begin{tabular}{lcc}
\hline & No. of cases & Percentage \\
\hline Gender & 78 & 66.1 \\
$\quad$ Male & 40 & 33.9 \\
$\quad$ Female & & \\
Age group & 97 & 82.2 \\
$\quad$ 41-50 years & 21 & 17.8 \\
$\quad$ 51-60 years & & \\
Experience & 40 & 33.9 \\
$\quad$ 5-10 years & 78 & 66.1 \\
$\quad$ 10 years and above & 16 & 13.6 \\
Educational qualification & 102 & 86.4 \\
$\quad$ Master's & & \\
$\quad$ Bachelor/HND & 24 & 20.3 \\
Professional qualification & 94 & 79.7 \\
$\quad$ Yes & & \\
$\quad$ No & &
\end{tabular}


Of the 118 respondents, $78(66 \%)$ were male. Most of the participants' age ranged between 41 to 50 years. Regarding job experience, about $70 \%$ of the respondents have well above 10 years experience with almost $90 \%$ having educational qualification of at least a Bachelor's degree or its equivalent (Higher National Diploma, HND).

\section{MEASUREMENTS}

As shown in the study's conceptual frame work (Figure 1.), the latent variables for this study are three, namely, financial reporting quality (FQR) as the explained variable, accounting staff competency (COM) as the predictor variable and professionalism (PRF) as the moderator variable. The present paper adopts relevance and faithful representation as dimensions to measure FRQ. Relevance is measured on items that determine the entity's ability to generate information about future operation and/or economic activities and whether the annual reports provide information about past operation and/or economic activities about the entity (IPSASB 2013; McDaniel et al. 2002). On the other hand, faithful representation is measured in terms of the ability of financial reports to be presented in a comprehensive and transparent manner and whether the annual reports present information regarding positive and/or negative financial events of the entity (IPSASB 2013). On the whole, FRQ was measured by four items adopted from the study of Bartov, Goldberg and Kim (2005), Jonas and Blanchet (2000), McDaniel, Martin and Maines (2002).

We used four items from the study of Ismail and Abidin (2010), Nguyen and Leclerc (2011), Puncreobutr et al. (2017), Saputra and Hutahaean (2016), Indriasih and Koeswayo (2014) to measure accounting staff competence. Professionalism was measured based on the studies of Christiaens (1999), Khumawala et al. (2014). In all the contructs, items were measured based on 7-point scale ranging from "1" "strongly disagree" to "7" "strongly agree".

\section{RESULTS}

Partial Least Square Structural Equation Modeling (PLS-SEM) was mainly used to analyse the data collected. The analysis was performed using smart PLS 3.0 software. The PLS path modeling is considered the most suitable technique in this study for important reasons. First, PLS path modeling allows for the simultaneous estimation of the relationship between constructs (structural model) and the relationship between indicators including their corresponding latent constructs (measurement model) (Willaby et al. 2015). Second, PLS is suitable and ideal for measuring predictive model (Bookstein \& Fornell 2014; Sarstedt et al. 2016). As such, since the aim of this paper is to predict implication of organizational contingency on financial reporting quality, it considers the use of PLS path modeling logical.

Using this tool, the score of the latent variables were calculated by the addition of the raw scores generated from the completed questionnaire regarding each variable, and then standardized by dividing the summated value by number of items (Kura, Shamsudin \& Chauhan 2015). But before conducting any analysis, it was imperative to screen the survey raw data to ensure that key assumption guiding multivariate analysis and PLS SEM statistical tool such as test of linearity and normality were not violated (Hair, Hult, Ringle \& Sarstedt 2014). However, these assumptions test was satisfactory and thus, the theoretical model was analyzed.

\section{RESULT OF PLS-SEM PATH MODEL}

According to literature on structural modeling, testing PLS-SEM path model involves two processes (Henseler, Ringle \& Sarstedt 2015) (1) testing the measurement model and (2) testing the structural model.

Measurement Model Results Measurement model, also known as the outer model, explains the relationships between indicators and their respective latent variables (Hair et al. 2014). Therefore, to assess the reliability and validity of the scales adopted in the present study, individual items reliability, internal consistency reliability, and discriminant validity were ascertained. Firstly, the outer loadings of each constructs is examined to ascertain the individual item reliability. In this study, this was examined based on standardized loading of all the latent variables (Hair, Sarstedt, Hopkins \& Kuppelwieser 2014) which is 0.707 and above. We deleted one item (PFR 02) whose loading was lower than 0.7 , reducing the items from 13 to 12 . Therefore, as shown in Table 3, for each latent variable, all the standardized loading of the remaining 12 items exceeds 0.7 , thus fulfilling the condition for the acceptable threshold. 
TABLE 3. Factor loading and reliability

\begin{tabular}{lccccc}
\hline Latent variables & Items & $\begin{array}{c}\text { Standardized } \\
\text { Loadings }\end{array}$ & Alpha & $\begin{array}{l}\text { Composite } \\
\text { Reliability }\end{array}$ & AVE \\
\hline Financial reporting quality & FRQ01 & 0.847 & 0.928 & 0.931 & 0.823 \\
& FRQ02 & 0.902 & & & \\
& FRQ03 & 0.936 & & & \\
& FRQ04 & 0.940 & & & 0.779 \\
Accounting staff competence & COM01 & 0.921 & 0.904 & 0.933 & \\
& COM02 & 0.896 & & & \\
& COM03 & 0.902 & & & \\
Professionalism & COM04 & 0.806 & & & \\
& PRF01 & 0.896 & 0.925 & 0.765 & \\
& PRF03 & 0.711 & & & \\
& PRF04 & 0.951 & & & \\
& PRF05 & 0.913 & & & \\
\hline
\end{tabular}

Secondly, the internal consistency was estimated using composite reliability coefficient of the measure which should be at least 0.70 or higher (Bagozzi 1988; Hair et al. 2014). In this study the composite reliability coefficient of the latent construct as indicated in Table 3 ranged from 0.765 to 0.933 , indicating that, the internal consistency reliability of the measures used in this study was deemed adequate. Thirdly, the convergent validity was ascertained using the average variance extracted (AVE) (Chin 1988). Fornell and Larcker (1981) suggested that the AVE value should be 0.50 or higher. As revealed in Table 3, the AVE was adequate (ranges from 0.762 to 0.823 ). This means that adequate convergent validity was established, as the scores of the AVE exceeds the minimum cut-off value. Fourthly, to ascertain the discriminant validity, Fornell and Larcker (1981) suggested that the discriminant validity is ascertained using the Average Variance Extracted (AVE). This was achieved by comparing the square root of the AVEs (diagonal entries) with the correlations between the latent constructs (offdiagonal entries). Therefore, discriminant validity is achieved if the diagonal values are significantly greater than the off-diagonal values in the corresponding rows and column. The result of the discriminant validity based on Fornell and Larcker (1981) criterion is presented on Table 4.

TABLE 4. Result of discriminant validity

\begin{tabular}{lrrr}
\hline Latent Constructs & 1 & 2 & 3 \\
\hline 1. Accounting Staff Competence & $\mathbf{0 . 8 8 2}$ & & \\
2. Financial Reporting Quality & 0.801 & $\mathbf{0 . 9 0 7}$ & \\
3. Professionalism & 0.055 & -0.07 & $\mathbf{0 . 8 7 3}$ \\
\hline
\end{tabular}

Based on Table 4, adequate discriminant validity was realized, because the values of the AVEs (values appear in bold) were greater than the correlations between the constructs.

Structural Model Results This section presents the significant assessment of the path coefficient for the main model of the study. This assessment test the relationship among the latent constructs (Hair et al. 2011). In this section, the results of the stated hypotheses relating to the conceptual framework as shown in figure 1 was presented. Table 5 and Figure 2 present the significant path coefficient for this study.

TABLE 5. Path coefficient result

\begin{tabular}{lllllllll}
\hline Hypotheses & Relations & Beta & Sd. Error & t-value & p-value & Finding & $\mathrm{R}^{2}$ & $\mathrm{Q}^{2}$ \\
\hline $\mathrm{H}_{1}$ & COM $\rightarrow$ FRQ & 0.812 & 0.039 & 20.903 & $0.000^{* *}$ & Supported & & \\
$\mathrm{H}_{2}$ & PRF $\rightarrow$ FRQ & -0.108 & 0.072 & 1.661 & $0.097^{* * *}$ & Not supported & & \\
$\mathrm{H} 3$ & COM x PRF $\rightarrow$ FRQ & 0.054 & 0.065 & 0.847 & $0.397^{* * *}$ & Not supported & 0.649 & 0.498 \\
\hline
\end{tabular}

Note: Dependent variable: Financial Reporting Quality

*Significant at 0.05 (two-tailed), **Significant at 0.01 (two-tailed),

***Significant at 0.1 (two-tailed) 


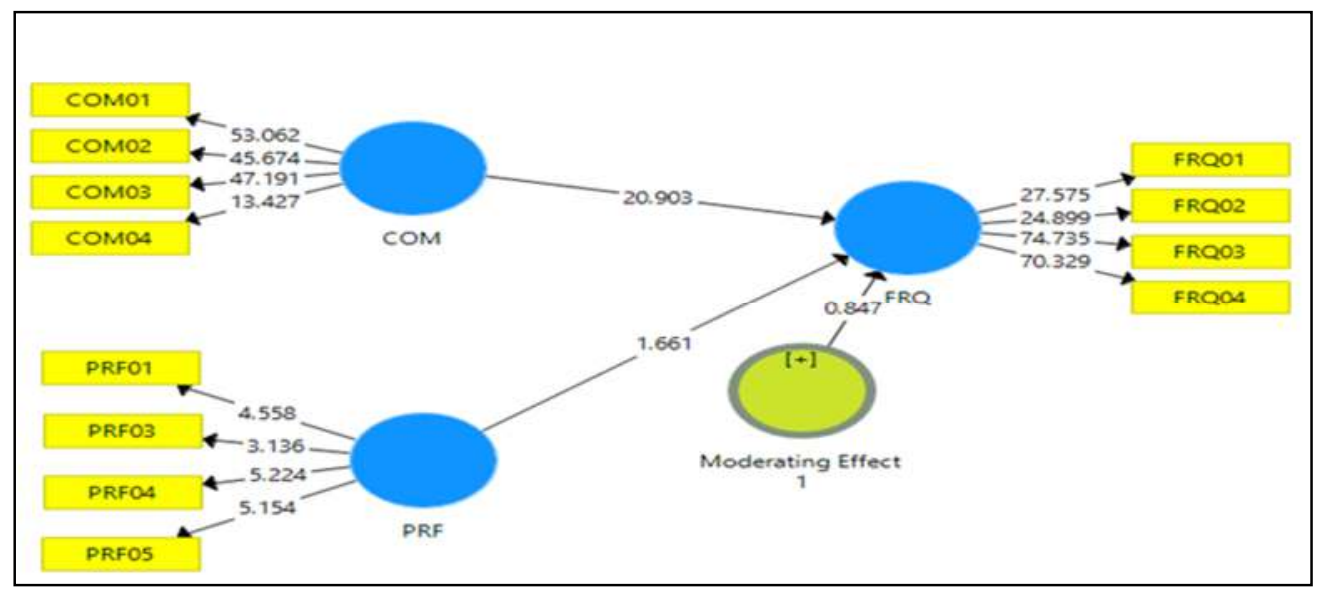

FIGURE 2. Structural model

Note: $\mathrm{FRQ}=$ financial reporting quality; $\mathrm{COM}=$ staff competence; $\mathrm{PRF}=$ Professionalism

As shown in Figure 2, the values shown near the arrows represent the t-values. These however, suggest that the relationship was significant at one-tailed test 0.05 level with critical t-value of \pm 1.645 . However, based on the hypotheses stated in this paper, hypothesis 1 predicts that accounting staff competency associate positively with perceived FRQ. The result in Table 5 reveals that accounting staff competence had a significant positive relation with FRQ $(\beta=0.812$, t-value $=20.903$ and $p$-value $<0.01)$. Thus, hypothesis 1 was supported. Similarly, the direct effect of professionalism was examined on FRQ. Based on the result on Table 5, professionalism showed negative association with FRQ $(\beta=-0.108$, t-value $=1.661$, P-value $<0.1)$ suggesting that hypothesis 2 not supported.

After ascertaining the significance of the path coefficient for the main model, next, we assess the structural model based on two criteria, including the R-squared values and predictive relevance of the study model. The Rsquare presents the combined effect of exogenous variables on endogenous variable (s). As shown in Table 4, the value of the R-square stood at 0.649 , suggesting that the two exogenous latent variables (i.e. competence and professionalism) collectively explained $64.9 \%$ of the variance in FRQ. As proposed by Falk and Miller (1992), $\mathrm{R}$-square value of 0.10 is an acceptable minimum value of predictive accuracy of determination score between exogenous and the endogenous variable(s). Therefore, it can be substantiated that the endogenous latent variable (FRQ) for this study, possess the acceptable level of R-square. Lastly, the predictive relevance $\left(\mathrm{Q}^{2}\right)$ of this study was calculated through blindfolding procedure in PLS 3.0 and assessed using the recommendation by Geisser (1974) and Stone (1974). According to Hensele, Ringle and Sinkovics (2009), a research model with $Q^{2}$ value greater than zero is considered to have predictive relevance. Therefore, result of this study shows a $\mathrm{Q}^{2}$ of 0.498 for the endogenous latent variable, suggesting that the model for this study possessed a good predictive relevance.

Testing Moderating Effect The moderation hypothesis was tested using Henseler and Chin (2010) product indicator approach. This approach allows the PLS-SEM procedure to detect and estimate the strength of the moderating effect of professionalism on the relationship between staff competence and perceived FRQ. Therefore, based on result of Table 5 and Figure 2, the items representing professionalism and staff competence towards predicting FRQ outcome $(\beta=0.054$, t-value $=0.847$, P-value $>0.1)$ was statistically insignificant. This indicates that, the moderating effect of professionalism on the relationship between staff competence and FRQ was not supported because there was no significant interaction effect between the constructs.

Consequently, inference from the statistical result concerning the first hypothesis for this study revealed a significant and positive relationship between accounting staff competence and perceived FRQ. This suggests that, staff competence in terms of knowledge, skills and experience have significant positive effect on the elaboration of quality accounting reports. The demographic profile of respondents' education for the survey testify to this result. Accordingly, over $85 \%$ of the respondents possessed first degree and a considerable number possessed Master's degree. This result is consistent with the study of Dwyer and Wilson (1989) who reported a significant and positive relationship between managers' level of education and FRQ. Similar result was also reported by Nur Afiah and Rahmatika (2014) and Saputra and Hutahaean (2016).

In the second hypothesis, we hypothesized that professionalism positively associate with perceived FRQ while applying international accounting standard. The result of the path model showed there is no positive relationship between professionalism and FRQ. In fact, the result revealed negative direction and insignificant relationship $(\beta=-0.108$, t-value $=1.661$ at two-tailed (1.96)) between professionalism and FRQ. This indicates that, there exist non-congruent relationship between institution of professional considerations and FRQ following the application of accounting standards. Moreover, the statistical result of the postulated hypothesis based on twotailed test explain the result of weak/poor motivation for the institution of professionalism in the accounting practice of the local government councils under study. This result is contrary to previous studies such as 
Christiaens (1999) and Khumawala et al (2014), that revealed significant positive relationship between professionalism and FRQ.

The plausible explanation for the above result suggests that, there exists low level of staff development in professional capabilities. For instance, out of 118 directors of finance in the sample surveyed, only about $20 \%$ possess professional accounting qualification (e.g. ICAN and ANAN). Again, concerning engaging the services of external professional consultants in the implementation of the new accounting standards (IPSAS), the mean score indicates a weak performance of the local governments in this direction (mean score $=3.667$, $\min$ score $=1$ and $\max =7)$.

Furthermore, hypothesis 3 is based on the conjecture that professionalism would moderate the relationship between staff competence and FRQ, such that the relationship between staff competence and elaboration of quality financial report will be strengthened for entities with high consideration for professionalism than those with low consideration. As shown in Table 5, professionalism did not interact significantly with the relationship between staff competence and FRQ $(\beta=0.054$, t-value $=0.847$, P-value $>0.1)$. Thus, the possible explanation for this effect reveals poor consideration for professionalism necessary to influence the competency of accounting staff to have significant effect for quality financial reporting in the context of the study.

However, the statistical result in hypothesis 3 is further reinforced by the outcome of the professionalism/FRQ relation. Thus, the technical implication describes the consequence, based on expectation in structural model that an insignificant result of a moderating factor in a direct relationship has high possibility for same for indirect mode (see example, Kura et al. 2015).

\section{IMPLICATION, LIMITATION AND DIRECTION FOR FUTURE RESEARCH}

Overall, the result of statistical inferences and justifications of the current study portends a significant implication for theory and practice. Firstly, additional empirical evidence has been provided in this paper, particularly in the area of organizational contingency and financial reporting quality which indicates that, despite the application of accounting standards, there are other organizational factors that also affect the quality of reporting outcomes. This area adds to extend the literature on accounting reporting, that accounting staff competence is an important organizational contingency that needs to be considered to enhance FRQ when adopting international accounting standards in the public sector.

Further, instead of focusing on direct relationship, which had shown inconclusive results by previous studies, this study introduced a moderating variable (professionalism) to test the relationship between staff competence and perceived FRQ. This approach however is unique to this study, as previous studies have not considered this interaction. The outcome of the moderating interaction notwithstanding indicates insignificant moderating effect, the lessons however adds to the literature on the need to adopt caution in the use of institutional factors, particularly in the context that shares similar demographic profile in respect of staff professional support as the present study.

Furthermore, the insignificant moderating effect of professionalism on the relationship between accounting staff competence and perceived FRQ, may suggest the need to adopt other institutional factors such as the influence of political factors in future research. According to Burns and Scapens (2000), politics plays key role in driving and shaping change processes, and they argued that the exigencies of politics is a critical tool for organizational participants or constituencies to adopt as an advantage to satisfy some vested interest over others. This is imperative, particularly as the global initiative in the public sector drives towards changes to internationalization of accounting practice and reporting. The imperatives and consequences of political pressure in the organizational settings has been observed to influence financial reporting outcomes (Bushman \& Piotroski 2006; Zimmerman 1977).

Moreover, this study may need to be replicated in different settings and context, using different samples and methods to further validate the revealed findings. Again, a longitudinal research design approach may be explored in future research, to detect and provide insights into changes over time. This may serve as an advantage over the present study that adopted a cross-sectional design, with causal inferences that could not be made to the population. In addition, the model for this study explained $64.9 \%\left(\mathrm{R}^{2}\right.$ - see Table 5) of the total variance of organizational contingencies that influences FRQ. This depicts that more studies are needed to uncover more potential organizational contingencies.

\section{CONCLUSION}

The objective of this paper was to carry out a study on local governments, with a view to examine the perceived role of accounting staff competency on quality of accounting reporting after adoption of the cash-basis IPSAS in Nigeria, and then investigating the interacting effect of professionalism as a moderating variable in the relationship. Despite its limitations, the present paper was able to reveal that accounting staff competency significantly and positively influences perceived FRQ, while the moderating effect of professionalism between 


\section{Jurnal Pengurusan 57(2019), Galley Proof \\ ISSN 0127-2713 Scopus, Cabell, ASEAN Citation Index (ACI) and MyCite Indexes}

the relationships was inconsequential. These results however, underscore the importance of staff competence as an important organizational factor to be considered in ensuring quality financial reporting while applying international accounting standards. The findings also demonstrate the lack of consideration for professionalism in the context of the study. Furthermore, this study provides some useful understanding into the perceptions of preparers of financial reports among local governments in Nigeria, particularly during the on-going adoption of the cash-basis IPSAS.

\section{REFERENCE}

Abbott, L.J., Daugherty, B., Parker, S. \& Peters, G.F. 2016. Internal audit quality and financial reporting quality: The joint importance of independence and competence. Journal of Accounting Research 54(1): 3-40.

Adhikari, P., Kuruppu, C. \& Matilal, S. 2013. Dissemination and institutionalization of public sector accounting reforms in less developed countries: A comparative study of the Nepalese and Sri Lankan central governments. Accounting Forum 37(3): 213-230.

Adhikari, P. \& Mellemvik, F. 2010. IPSASs in developing countries: A case of Nepalese central government. International Journal on Governmental Financial Management, x(2): 36-48.

Akhidime, A. \& Ekiomado, E.B. 2014. Adoption and implementation of international financial reporting standards (IFRS) in Nigeria: Auditors' perspectives. International Journal of Development and Sustainability 5(2): 108-112.

Anessi-Pessina, E., Nasi, G. \& Steccolini, I. 2008. Accounting reforms: Determinants of local governments' choices. Financial Accountability \& Management 24(3): 0267-4424.

Association of Professional Engineers Geologists and Geographicists of Alberta. 2004. Concept of professionalism. 1500 Scotia Edmonton, Alberta T5J 4A2

Arthur, J.B. 2011. Do HR system characteristics affect the frequency of interpersonal deviance in organizations? The role of team autonomy and internal labor market practices. Industrial Relations 50(1): 30-56.

Ashburner, L., Ferlie, E. \& FitzGerald, L. 1996. Organizational transformation and top-down change: The case of the NHS. British Journal of Management 7(1): 1-16.

Ayobami, O. 2014. Accountability and financial reporting issues in Nigeria: Considering a change from cash accounting to accrual accounting. International Journal of Management Science and Humanity 2(1): 3042.

Bageva, A. 2010. The quality of published accounting information in Russia. Issues in Accounting Education. Available at https://doi.org/10.2308/iace.2002.17.4.411

Bagozzi, R.R. 1988. On the evaluation of structural equation models. Journal of the Academy of Marketing Science 16(1): 074-094.

Balios, D., Poutos, E. \& Toudas, K. 2013. Concepts, regulations and institutional issues of IPSAS: A critical review. European Journal of Business and Social Sciences 2(1): 43-54.

Ball, R., Robin, A. \& Wu, J.S. 2003. Incentives versus standards: Properties of accounting income in four East Asian countries. Journal of Accounting and Economics 36(1-3 SPEC. ISS.): 235-270.

Bakhtiari, M. \& Azimifar, M. 2013. The impact of professional ethics on financial reporting quality. Advances in Enviromental Biology 7(10): 2862-2866.

Baron, R.M. \& Kenny, D. 1986. The moderator-mediator variable distinction in social psychological research: Conceptual, strategic, and statistical considerations. Journal of Personality and Social Psychology 51(6): 1173-1182.

Barth, M.E., Beaver, W.H. \& Landsman, W.R. 2001. The relevance of the value relevance literature for financial accounting standard setting: Another view. Journal of Accounting and Economics 31: 77-104.

Barth, M.E., Landsman, W.R. \& Lang, M.H. 2008. International accounting standards and accounting quality. Journal of Accounting Research 46(3): 467-498.

Bartov, E., Goldberg, S.R. \& Kim, M. 2005. Comparative value relevance among german, u.s., and international accounting standards: A German stock market perspective. Journal of Accounting, Auditing and Finance 20(2): 95-119

Berry, C.M., Ones, D.S. \& Sackett, P.R. 2007. Interpersonal deviance, organizational deviance, and their common correlates: A review and meta-analysis. Journal of Applied Psychology 92(2): 410-424.

Bisogno, M., Santis, S. \& Tommasetti, A. 2015. Public-sector consolidated financial statements: An analysis of the comment letters on IPSASB's exposure draft No. 49. International Journal of Public Administration, 38(4): 311-324.

Blalock Jr., H.M. 1979. The presidential address: Measurement and conceptualization problems: The major obstacle to integrating theory and research. American Sociological Review 44(6): 881-894.

Bookstein, F.L.L. \& Fornell, C. 1982. Two structural equation models: Lisrel and PLS applied to consumer exitvoice theory. Journal of Marketing 19(4): 440-452.

Bots, J.M., Groenland, E. \& Swagerman, D.M. 2009. An empirical test of Birkett's competency model for 
management accountants: Survey evidence from Dutch practitioners. Journal of Accounting Education 27(1): 1-13.

Braam, G. \& Beest, F. 2013. Conceptually-based financial reporting quality assessment an empirical analysis on quality differences between UK annual reports and US 10-K reports. NiCE Working Paper, November: 13106

Broadbent, J. \& Guthrie, J. 2008. Public sector to public services: 20 years of "contextual” accounting research. Accounting, Auditing \& Accountability Journal 21(2): 129-169.

Brusca, I. \& Martınez, J.C. 2015. Adopting international public sector accounting standards: A challenge for modernizing and harmonizing public sector accounting. International Review of Administrative Sciences International 82(4): 724-744.

Burns, J. \& Scapens, R.W. 2000. Conceptualizing management accounting change: An institutional framework. Management Accounting Research 11: 3-25.

Bushman, R.M. \& Piotroski, J.D. 2006. Financial reporting incentives for conservative accounting: The influence of legal and political institutions. Journal of Accounting and Economics 42: 107-148.

Carnegie, G.D. \& Napier, C.J. 2010. Traditional accountants and business professionals: Portraying the accounting profession after Enron. Accounting, Organizations and Society 35(3): 360-376.

Chan, J.L. 2008. International public sector accounting standards: Conceptual and institutional issues. The Harmonization of Government 21: 1-15.

Chan, J.L., Jones, R.H. \& Lüder, K.G. 1996. Modeling governmental accounting innovations: An assessment and future research directions. Research in Government and Non-Profit Accounting 9: 1-9.

Chin, W.W. 1988. The partial least squares approach to structural equation modeling. In Modern Methods for Business Research, edited by G.A. Marcoulides. Mahwah, NJ: Lawrence Erlbaum.

Christiaens, J. 1999. Financial accounting reform in Flemish municipalities: An empirical investigation. European Accounting Review 15(1): 803-804.

Cohen, D.A. 2003. Quality of financial reporting choice: Determinants and economic consequences. Available at https://ssrn.com/abstract=422581 or http://dx.doi.org/10.2139/ssrn.422581

Cooper D.R. \& Schindler P.S. 2006. Business Research Methods. 9th edn. New York: McGraw-Hill.

Diamantopoulos A. \& Siguaw J. A. 2006. Formative versus reflective indicators in organizational measure development: A comparison and empirical illustration. British Journal of Management 17(4): 263-282.

Darwanis, D., Saputra, M. \& Kartini, K. 2016. Effect of professionalism, competence, knowledge of financial management, and intensity guidance apparatus inspectorate for quality of financial statements. Broad Research in Accounting, Negotiation and Distribution 6(1): 32-40.

DiMaggio, P.J. \& Powell. W. 1991. Introduction. In The New Institutionalism in Organizational Analysis, edited by W.W. Powell \& P.J. DiMaggio, 1-38. Chicago: University of Chicago Press.

Dingle, J. 1995. Analysing the competence requirements of managers. Management Development Review 8(2): 30-36.

Dwyer, P.D. \& Wilson, E.R. 1989. An empirical investigation of factors affecting the timeliness of reporting by municipalities. Journal of Accounting and Public Policy 8(1): 29-55.

Espositi, G., Francesca, F. \& Bosco, V. 2015. Examining perception of competency through practicum competencies outline. European Journal of Training and Development 39(8): 700-720.

Evetts, J. 2013. Professionalism: Value and ideology. Current Sociology 61(5-6): 778-796.

FASB 1980. Statement of Financial Accounting Concepts No. 2. Qualitative Characteristics of Accounting Information. Norwalk.

Falk, R.F. \& Miller, N.B. 1992. A Primer for Soft Modeling. Akron: University of Akron Press.

Fornell, C. \& Larcker, D. 1981. Structural equation models with unobservable variables and measurement error: Algebra and statistics. Journal of Marketing Research 18(3): 382-388.

Garuba, A.O. \& Donwa, P. 2011. The challenges of adopting international financial reporting system in Nigeria. JORIND 1(9): 313-319.

Geisser, S. 1974. A predictive approach to the random effect model. Biometrika 61(1): 101-107.

Gjorgieva-Trajkovska, O., Koleva, B. \& Nikoloski, K. 2017. The importance of financial reporting for investment decision making. In Thirteenth International Scientific Conference. 25th - 28th May, 2017. Budva, Montenegro.

Guthrie, J., Olson, O. \& Humphrey, C. 1999. Debating developments in New Public financial management: The let of global theoring and some new waysforward. Financial Accountability 15(11): 209-228.

Hair, J.F., Hult, G.T.M., Ringle, C.M. \& Sarstedt, M. 2014. A primer on partial least squares structural equation modelling (PLS-SEM). Thousand Oaks: Sage.

Hair, J.F., Sarstedt, M., Hopkins, L. \& Kuppelwieser, V.G. 2014. Partial least squares structural equation modeling (PLS-SEM). European Business Review 26(2): 106-121.

Hair, J.F., Ringle, C.M. \& Sarstedt, M. 2011. PLS-SEM: Indeed a silver bullet. Journal of Marketing Theory and Practice 19(2): 139-152. 


\section{Jurnal Pengurusan 57(2019), Galley Proof \\ ISSN 0127-2713 Scopus, Cabell, ASEAN Citation Index (ACI) and MyCite Indexes}

Healy, P.M. \& Wahlen, J.M. 1999. A review of the earnings management literature and its implications for standard setting. American Accounting Association 13(4): 365-383.

Herbert, W.E., Ene, E. \& Tsegba, I. 2014. Globalization of financial reporting: Obstacles to international financial reporting standards ( IFRS ) adoption in Nigeria. Asian Journal of Business and Management Sciences 3(12): 25-41.

Henseler, J. \& Chin, W. W. 2010. A comparison of approaches for the analysis of interaction effects between latent variables using partial least squares path modeling. Structural Equation Modeling 17(1): 82-109.

Henseler, J., Ringle, C.M. \& Sarstedt, M. 2015. A new criterion for assessing discriminant validity in variancebased structural equation modeling. Journal of the Academy of Marketing Science 43(1): 115-135.

Herath, K.S. \& Albarqi, N. 2017. Financial reporting quality: A literature review. International Journal of Business Management and Commerce 2(2): 1-14.

Hirst, D.E., Hopkins, P.E. \& Wahlen, J.M. 2004. Fair values, income measurement, and bank analysts risk and valuation judgements. The Accounting Review 79(2): 453-472.

Hood, C. 1995. The new public management in the 1980s: Variations on a theme. Accounting Organizations and Society 20(2/3): 93-109.

Hope, O. 2003. Disclosure practices, enforcement of accounting standards, and analysts' forecast accuracy: An international study. Journal of Accounting Researchesearch 41(2): 235-272.

Hyndman, N. \& Connolly, C. 2011. Accruals accounting in the public sector: A road not always taken. Management Accounting Research 22(1): 36-45.

IASB. 2010. Conceptual framework for financial reporting. International Financial Reporting Standards (Vol. 87). Available at https://doi.org/ISBN: 978-1-907026-69-0 Copyright

IFAC. 2009a. 2009 IFAC Handbook of International Public Sector Accounting (IPSAS) pronouncements.

IFAC. 2009b. Financial reporting under the cash basis of accounting part 2: Encouraged additional disclosures. International Federation of Accountants. 2015. International Public Sector Accounting Standards Board Handbook of International Public Sector Accounting Pronouncements 2012 Edition (II).

Indriasih, D. \& Koeswayo, P.S. 2014. The effect of government apparatus competence and the effectiveness of government internal control toward the quality of financial reporting and its impact on the performance accountability ( survey of all units local government in Tegal city - central Ja. South East Asia Journal of Contemporary Business, Economics and Law 5(1): 90-100.

IPSASB. 2010. Conceptual Framework for general purpose financial reporting by public sector entities : Elements and recognition in financial statements.

IPSASB. 2013. Conceptual framework for general purpose financial reporting by public sector entities: Presentation in general purpose financial reports.

Ismail, R. \& Abidin, S.Z. 2010. Impact of workers' competence on their performance in the Malaysian private service sector. Business and Economic Horizons 2(8): 25-30.

Jara, E.G., Ebrero, A.C. \& Zapata, R.E. 2011. Effect of international financial reporting standards on financial information quality. Journal of Financial Reporting and Accounting 9(2): 176-196.

Jones, R. \& Caruana, J. 2015. Governmental accounting in Malta towards IPSAS within the context of the European Union. International Review of Administrative Science 82(4): 745-762.

Jonas, G.J. \& Blanchet, J. 2000. Assessing quality of financial reporting. American Accounting Association, Accounting Horizons 14(3): 353-363.

Judge, W., Li, S. \& Pinsker, R. 2010. National adoption of international accountingstandards: An institutional perspective. Corporate Governance 18(3): 161-174

Kasim, E.Y. 2015. Effect of government accountants competency and implementation of internal control to the quality of government financial reporting. International Journal of Business, Economics and Law 8(1): 97105.

Khumawala, S., Marlowe, J. \& Neely, D. 2014. Accounting professionalism and local government Gaap. Journal of Budgeting, Accounting \& Financial Management 26(2): 292-312.

Kura, K.M., Shamsudin, F.M. \& Chauhan, A. 2015. Does self-regulatory efficacy matter? Effects of punishment certainty and punishment severity on organizational deviance. SAGE Open 5(2).

Larcker, D.F. \& Lessig, V.P. 1980. Perceived usefulness of information: A psychometric examination. Decision Sciences 11(1): 121-134.

Laswad, F. \& Redmayne, N.B. 2015. IPSAS or IFRS as the framework for public sector financial reporting? New Zealand preparers' perspectives. Australian Accounting Review 25(2): 175-184.

Lüder, K.G. 1992. A contingency model of governmental accounting innovations in the political- administrative environment. Research in Government and Non-Profit Accounting 7: 99-127.

Madawaki, A. 2014. Adoption of international financial reporting standards in developing countries: The case of Nigeria. International Journal of Business and Management 7(3): 152-161.

Maigoshi, Z.S. 2014. The impact of mandatory adoption of international financial reporting standard on accounting quality in Nigeria. Unplished Msc Dissi., University Utara Malaysia, Sintok Malaysia. 
Maines, L.A. \& Wahlen, J.M. 2006. The nature of accounting information reliability: Inferences from archival and experimental research. Accounting Horizons 20(4): 399-425.

Mataira, K. \& Van Peursem, K.A. 2010. An examination of disciplinary culture: Two professional accounting associations in New Zealand. Accounting Forum 34(2): 109-122.

Mbobo, M.E. \& Ekpo, N.B. 2016. Operationalising the qualitative characteristics of financial reporting. International Journal of Finance and Accounting 5(4): 184-192.

McDaniel, L., Martin, R.D. \& Maines, L.A. 2002. Evaluating financial reporting quality: The effects of financial expertise vs. financial literacy. Accounting Review 77(SUPPLEMENT): 139-167.

Moehrle, S.R., Anderson, K.L., Ayres, F.L., Bolt-Lee, C.E., Debreceny, R.S., Dugan, M.T. \& Plummer, E. 2009. The impact of academic accounting research on professional practice: An analysis by the AAA research impact task force. Accounting Horizons 23(4): 411-456.

Musa, A. 2015. International financial reporting standards and financial reporting quality among Nigerian listed companies. Othman Yeop Abdullah Graduate School of Business, Universiti Utara Malaysia.

Mustapha, M., Ku Ismail, K.N.I. \& Ahmad, H.N. 2017. Organizational contingency and financial reporting quality in the public sector while adopting cash-basis IPSAS: A conceptual approach. Asian Journal of Multidisciplinary Studies 5(12): 1-13.

Nguyen, N. \& Leclerc, A. 2011. The effect of service employees' competence on financial institutions' image: Benevolence as a moderator variable. Journal of Services Marketing 25(5): 349-360.

Nongo, J.Y. 2014. IPSAS issues for public finance management executive. outlook Ey com/IPSAS.

Nur Afiah, N. \& Rahmatika, D.N. 2014. Factors influencing the quality of financial reporting and its implications on good government governance (research on local government Indonesia). International Journal of Business, Economics and Law 5(1): 111-121.

Nyor, T. 2013. Financial reporting quality of Nigeria Firms: Users' perception. International Journal of Business and Social Science 4(13): 273-279.

Patel, A. \& Prasad, P. 2013. Issues and challenges in the adoption of public sector accounting standards: A developing country perspective 8(2): 433.

Pina, V. \& Torres, L. 2003. Reshaping public sector accounting: An international comparative view. Canadian Journal of Administrative Sciences 20(4): 334-350.

Pina, V., Torres, L. \& Yetano, A. 2009. Accrual accounting in EU local governments: One method, several approaches. European Accounting Review 18(4): 765-807.

Pounder, B. 2013. Measuring Accounting Quality. Financial Reporting 1(5): 1-4.

Puncreobutr, V., Chumark, C. \& Tipajatuporn, K. 2017. Correlation between accountants' competence and the quality of financial reports of SMEs in the Province of Nakorn Nayok. Available at https://ssrn.com/ abstract $=2908676$

Robbins, W.A. \& Austin, K.R. 1986. Disclosure quality in governmental financial reports: An assessment of the appropriateness of a compound measure. Journal of Accounting Research 24(2): 412-421.

Salakjit, N. \& Phapruke, U. 2011. Accounting professionalism, financial reporting quality and information usefulness: Evidence from exporting firms in Thailand. Journal of International Business and Economics 11(4): 155-166.

Saputra, M. \& Hutahaean, S.M.M. 2016. The effect of financial management knowledge, competence and supervision act of the government's internal control officer on the quality of government's performance accountability report evaluation. Academic Journal of Economic Studies 2(2): 20-31.

Sarstedt, M., Hair, J.F., Ringle, C.M., Thiele, K.O. \& Gudergan, S.P. 2016. Estimation issues with PLS and CBSEM : Where the bias lies ! Journal of Business Research 69(10): 3998-4010.

Sekaran, U. \& Bougie, R. 2010. Research Methods for Business: A Skill-Building Approach. 5th ed. Haddington: John Wiley \& Sons.

Setiyawati, H. 2013. The effect of internal accountants' competence, managers' commitment to organizations and the implementation of the internal control system on the quality of financial reporting. International Journal of Business and Management Invention 2(11): 19-27.

Staubus, G.J. 2004. On Brian P. West's professionalism and accounting rules. Abacus 40(2): 139-156.

Svensson, L.G. 2006. New professionalism, trust and competence: Some conceptual Remarks and empirical data. Current Sociology 54(4): 579.

Tasios, S. \& Bekiaris, M. 2012. Auditor's perceptions of financial reporting quality: The case of Greece. International Journal of Accounting and Financial Reporting 2(1): 57-74.

Tarus, M.J., Muturi, D. \& Kwasira, J. 2015. Determinants of accurate financial statements reporting in listed banks in Kenya; A survey of commercial banks in Nakuru Town. Journal of Business and Management 17(4): 7986.

Torres, L. 2004. Accounting and accountability: Recent developments in government financial information systems. Public Administration and Development 24(5): 447-456.

Willaby, H.W., Costa, D.S.J., Burns, B.D., MacCann, C. \& Roberts, R.D. 2015. Testing complex models with 
small sample sizes: A historical overview and empirical demonstration of what Partial Least Squares (PLS) can offer differential psychology. Personality and Individual Differences 84: 73-78.

Yaşar, M.F., Ünal, Ö.F. \& Zaim, H. 2013. Analyzing the effects of individual competencies on performance: A field study in services industries in Turkey. Journal of Global Strategic Management 2(7): 67-67.

Young, J.J. \& Mouck, T. 2012. Objectivity and the role of history in the development and review of accounting standards. Accounting, Auditing \& Accountability Journal 9(3): 127-147.

Zimmerman, J.L. 1977. Discussion of the municipal accounting maze: An analysis of political incentives. Journal of Accounting Research 15(1977): 107-144.

Maruf Mustapha (corresponding author)

Department of Local Government \& Development Studies

Faculty of Administration

Ahmadu Bello University

Kaduna State Nigeria Zaria, NIGERIA.

E-Mail: mmustaphaphd@gmail.com

Ku Nor Izah Ku Ismail

Tunku Puteri Intan Safinaz School of Accountancy

Universiti Utara Malaysia

06010 UUM Sintok, Kedah, MALAYSIA.

E-Mail: norizah@uum.edu.my

Halimah Nasibah Ahmad

Tunku Puteri Intan Safinaz School of Accountancy

Universiti Utara Malaysia

06010 UUM Sintok, Kedah, MALAYSIA.

E-Mail: halimahmad@uum.edu.my 


\section{APPENDIX A}

Overview of the measurement items used to operationalize Financial Reporting Quality (FRQ), Accounting Staff Competence (COM) and Professionalism (PRF) (Including the Measurement Scales)

FINANCIAL REPORTING QUALITY

\begin{tabular}{|c|c|c|c|c|}
\hline Code & Question & Scale & Concept & Literature \\
\hline FRQ 01 & $\begin{array}{l}\text { The annual financial report concerning your } \\
\text { local government discloses information } \\
\text { about future operation and/or future } \\
\text { economic activities of the council. }\end{array}$ & $\begin{array}{l}1 \text { - Very low } \\
2-\text { Low } \\
3-\text { Somewhat low } \\
4-\text { Neutral } \\
5 \text { - Somewhat high } \\
6 \text { - High } \\
7 \text { - Very high }\end{array}$ & Predictive value & $\begin{array}{l}\text { McDaniel, Martin, } \\
\text { and Maines (2002), } \\
\text { Van Beest, Braam } \\
\text { and Boelens (2009) }\end{array}$ \\
\hline FRQ 02 & $\begin{array}{l}\text { The annual financial report concerning your } \\
\text { local government provides information } \\
\text { about past operation and/or past economic } \\
\text { activities of the council. }\end{array}$ & $\begin{array}{l}1-\text { Very low } \\
2-\text { Low } \\
3-\text { Somewhat low } \\
4-\text { Neutral } \\
5 \text { - Somewhat high } \\
6 \text { - High } \\
7-\text { Very high }\end{array}$ & $\begin{array}{l}\text { Confirmatory } \\
\text { value }\end{array}$ & $\begin{array}{l}\text { McDaniel, Martin, } \\
\text { and Maines (2002), } \\
\text { Van Beest, Braam } \\
\text { and Boelens (2009) }\end{array}$ \\
\hline FRQ 03 & $\begin{array}{l}\text { Annual Financial report concerning your } \\
\text { local government are presented in a } \\
\text { comprehensive and transparent manner. }\end{array}$ & $\begin{array}{l}1-\text { Very low } \\
2-\text { Low } \\
3-\text { Somewhat low } \\
4-\text { Neutral } \\
5-\text { Somewhat high } \\
6 \text { - High } \\
7-\text { Very high }\end{array}$ & $\begin{array}{l}\text { Completeness } \\
\text { and error free }\end{array}$ & $\begin{array}{l}\text { Bartov, Goldberg and } \\
\text { Kim (2005), Jonas } \\
\text { and Blanchet }(2000)\end{array}$ \\
\hline FRQ 04 & $\begin{array}{l}\text { Positive and/or negative financial } \\
\text { events concerning your local } \\
\text { government are disclosed by the annual } \\
\text { financial report. }\end{array}$ & $\begin{array}{l}1-\text { Very low } \\
2-\text { Low } \\
3-\text { Somewhat low } \\
4-\text { Neutral } \\
5-\text { Somewhat high } \\
6 \text { - High } \\
7-\text { Very high }\end{array}$ & Neutral & $\begin{array}{l}\text { Bartov, Goldberg and } \\
\text { Kim (2005), Jonas } \\
\text { and Blanchet }(2000)\end{array}$ \\
\hline Code & Question & & Concept & Literature \\
\hline COM 01 & $\begin{array}{l}\text { Accounting staff in your LG } \\
\text { possess the requisite } \\
\text { educational qualification to } \\
\text { implement the requirement of } \\
\text { cash-basis IPSAS }\end{array}$ & $\begin{array}{l}\text { trongly disagree, } 2- \\
\text { gree, } \\
\text { omewhat disagree, } \\
\text { Neither agree nor } \\
\text { ree } \\
\text { Somewhat agree, } 6 \text { - } \\
\text { e, } \\
\text { trongly agree }\end{array}$ & Knowledge & $\begin{array}{l}\text { Saputra and } \\
\text { Hutahaean (2016) }\end{array}$ \\
\hline COM 02 & $\begin{array}{l}\text { Accounting staff in your LG } \\
\text { possess the requisite technical } \\
\text { skills to implement the } \\
\text { provisions of the cash-basis } \\
\text { IPSAS in presentation of the } \\
\text { annual financial report. }\end{array}$ & $\begin{array}{l}\text { trongly disagree, } 2 \text { - } \\
\text { gree, } \\
\text { omewhat disagree, } \\
\text { Neither agree nor } \\
\text { ree } \\
\text { Somewhat agree, } 6 \text { - } \\
\text { e, } \\
\text { trongly agree }\end{array}$ & Skills & $\begin{array}{l}\text { Indriasih } \\
\text { Koeswayo (2014) }\end{array}$ \\
\hline COM 03 & $\begin{array}{l}\text { Accounting staff in my LG } \\
\text { possess adequate experience } \\
\text { in accounting practices to } \\
\text { implement the guidelines of } \\
\text { the cash-basis IPSAS. }\end{array}$ & $\begin{array}{l}\text { trongly disagree, } 2- \\
\text { gree, } \\
\text { omewhat disagree, } \\
\text { Neither agree nor } \\
\text { ree }\end{array}$ & Experience & $\begin{array}{l}\text { Ismail and Abidin } \\
\text { (2010), Nguyen and } \\
\text { Leclerc (2011) }\end{array}$ \\
\hline
\end{tabular}


Accounting staff in your local government are familiar with the current development in accounting practices in the performance of their work.
5 - Somewhat agree, 6 -

Agree,

7 - Strongly agree

1 - Strongly disagree, 2 Disagree,

3 - Somewhat disagree,

4 - Neither agree nor

disagree

5 - Somewhat agree, 6 -

Agree,

7 - Strongly agree
Awareness - Puncreobutr et al. current (2017), Saputra and

accounting Hutahaean (2016)

\section{PROFESSIONALISM}

\begin{tabular}{|c|c|c|c|c|}
\hline Code & Question & Scale & Concept & Literature \\
\hline PRF 01 & $\begin{array}{l}\text { Your local government engaged the } \\
\text { services of an external accounting } \\
\text { professional consultants regarding the } \\
\text { implementation of the cash-basis } \\
\text { IPSAS accounting system }\end{array}$ & $\begin{array}{l}\text { 1-Strongly disagree } \\
2 \text { - Disagree } \\
3 \text { - Somewhat disagree } \\
4-\text { Neither agree nor } \\
\text { disagree } \\
5 \text { - Somewhat agree } \\
6 \text { - Agree } \\
7 \text { - Strongly agree }\end{array}$ & $\begin{array}{l}\text { Professional } \\
\text { consultants }\end{array}$ & $\begin{array}{l}\text { Khumawala, } \\
\text { Marlowe and Neely } \\
\text { (2014) }\end{array}$ \\
\hline PRF 02 & $\begin{array}{l}\text { One or more accounting staff of } \\
\text { your LG is a member of a } \\
\text { professional accounting institution } \\
\text { (e.g. ICAN or ANAN) }\end{array}$ & $\begin{array}{l}1 \text { - Strongly disagree } \\
2 \text { - Disagree } \\
3 \text { - Somewhat disagree } \\
4-\text { Neither agree nor } \\
\text { disagree } \\
5 \text { - Somewhat agree } \\
6 \text { - Agree } \\
7 \text { - Strongly agree }\end{array}$ & $\begin{array}{l}\text { Membership of } \\
\text { professional } \\
\text { institution }\end{array}$ & $\begin{array}{l}\text { Khumawala, } \\
\text { Marlowe and Neely } \\
\text { (2014) }\end{array}$ \\
\hline PRF 03 & $\begin{array}{l}\text { The membership of the } \\
\text { professional accounting institutes } \\
\text { helps in the implementation of the } \\
\text { cash-basis IPSAS in your local } \\
\text { government. }\end{array}$ & $\begin{array}{l}\text { 1- Strongly disagree } \\
2 \text { - Disagree } \\
3 \text { - Somewhat disagree } \\
4-\text { Neither agree nor } \\
\text { disagree } \\
5 \text { - Somewhat agree } \\
6 \text { - Agree } \\
7 \text { - Strongly agree }\end{array}$ & $\begin{array}{l}\text { Professional } \\
\text { guide }\end{array}$ & Christiaens (1999) \\
\hline PRF 04 & $\begin{array}{l}\text { Conformity with accounting practices } \\
\text { and standards in your local } \\
\text { government is usually monitored by } \\
\text { designated institution/body since the } \\
\text { adoption of the new accounting reform } \\
\text { (cash-basis IPSAS) }\end{array}$ & $\begin{array}{l}1 \text { - Strongly disagree } \\
2 \text { - Disagree } \\
3 \text { - Somewhat disagree } \\
4-\text { Neither agree nor } \\
\text { disagree } \\
5 \text { - Somewhat agree } \\
6 \text { - Agree } \\
7 \text { - Strongly agree }\end{array}$ & $\begin{array}{l}\text { Professional } \\
\text { regulatory body } \\
\text { (ethics) }\end{array}$ & Christiaens (1999) \\
\hline PRF 05 & $\begin{array}{l}\text { Your local government engaged its } \\
\text { accounting staff in professional } \\
\text { training and education on how to } \\
\text { implement and apply the cash-basis } \\
\text { IPSAS. }\end{array}$ & $\begin{array}{l}1 \text { - Strongly disagree } \\
2-\text { Disagree } \\
3 \text { - Somewhat disagree } \\
4-\text { Neither agree nor } \\
\text { disagree } \\
5 \text { - Somewhat agree } \\
6 \text { - Agree } \\
7 \text { - Strongly agree }\end{array}$ & $\begin{array}{l}\text { Professional } \\
\text { Training }\end{array}$ & Christiaens (1999) \\
\hline
\end{tabular}

